\title{
Nutrient Content and Acceptability of Biscuits Subtitutes from Flour of Mackerel Fish (Rastrelliger Kanagurta L)
}

\author{
Nadimin $^{1}$, Abdullah Thamrin ${ }^{2}$, Adriyani Adam ${ }^{3}$, Hijrayani $^{4}$ \\ ${ }^{1}$ Assosiate Professor, Nutrition Department, Health Polytechnic of Makassar, Indonesia, ${ }^{2,3}$ Assistant Profesor, \\ Nutrition Department, Health Polytechnic of Makassar, Indonesia, ${ }^{4}$ Student, Nutrition Department, Health \\ Polytechnic of Makassar, Indonesia
}

\begin{abstract}
Mackerel (Rastrelliger kanagurta $L$ ) is widely available and contains nutrients. This fish has potential for prevention malnutrition problems in Indonesia, especially in South Sulawesi Province, but their utilization is not optimal. The aims of this study was to determine nutrient content and acceptability biscuits subtitutes from flour of mackerel fish. The design of this study was experimental by making biscuits through substitution with mackerel fish flour and divided into four concentration formulas, F0 $=0 \%, \mathrm{~F} 1=5 \%, \mathrm{~F} 2=10 \%, \mathrm{~F} 3=15 \%$. Each biscuit was subjected to a acceptability test using the organoleptic test method using hedonic scale. Analysis of protein content using the Kjehdal method, fat content using the shoxlet method, carbohydrates content using the Luff Chroll method and minerals content using with AAS. The results of this study that substitution of mackerel flour reduced the acceptance of biscuits, although the decrease was not significant in terms of color $(p=0.061)$ and texture $(p=0.356)$. A significant decrease in the acceptability score was seen in the aroma aspect $(p=0.000)$ and the taste aspect $(p=0.000)$. F1 biscuits are the best formula, having a carbohydrate content of $62.49 \%, 18.35 \%$ fat, $10.72 \%$ protein, $10.83 \mathrm{mg} / \mathrm{L}$ zinc and $230.95 \mathrm{mg} / \mathrm{L}$ iron. The substitution of mackerel flour does not affect for acceptability of the color and texture aspects, but affects for aroma and taste, especially if the concentration of the addition is too high. Protein, iron, and zinc levels increased in the biscuits formula that was substituted for mackerel fish meal.
\end{abstract}

Keywords: Biscuits, acceptability, nutrient content, mackerel.

\section{Introduction}

Mackerel (Rastrelliger kanagurta L) is a potential natural resource, widely available in South Sulawesi and has the potential for essential nutrients, especially omega 3 and omega 6 which function for growth and development. Some of the advantages of mackerel are relatively cheap price, high availability so that it is easy to obtain, and has a high nutritional value. Mackerel contains high enough nutrients, functions for growth and maintains a healthy body. Every 100 grams of mackerel fish contains $22 \mathrm{~g}$ of protein, $3.4 \mathrm{~g}$ fat, $20 \mathrm{mg}$ calcium,

\footnotetext{
Corresponding Author: Nadimin

Assosiate Professor, Nutrition Department, Health Polytechnic of Makassar, Indonesia e-mail: nadimingizi66@gmail.com
}

$200 \mathrm{mg}$ phosphorus, $1 \mathrm{~g}$ iron, vitamin A 30 SI and vitamin $\mathrm{B} 10.05 \mathrm{mg}^{(1)}$. On the other hand, mackerel is a perishable foodstuff that requires further handling and processing ${ }^{(2,3)}$

The use of mackerel fish as long as it is still limited for consumption through food dishes. Currently, mackerel fish has not been used optimally because it has not been found in mackerel that is practical and liked by children ${ }^{(4)}$. The group of children who are prone to malnutrition generally has a low fish consumption habit so it is necessary to diversify the processing of fishery products, for example through the manufacture of fish meal. Diversification of fishery product processing will increase the added value of fresh fish and reduce the perishable nature of fresh fish ${ }^{(5)}$. The addition of fish meal to a food product will increase the nutritional value of the product ${ }^{(6)}$ One of the efforts to increase consumption of mackerel in Indonesia is by processing 
it into local food which is generally consumed by the public. One of the local foods that is often consumed is biscuits. Biscuits are usually consumed as a snack. Biscuits with a mixture of flour and fish have better quality than biscuits without fish mixture

Biscuits are a popular snack, especially for children, with a variety of flavors, textures and styles. Biscuits have become one of the choices in nutritional interventions in Indonesia, given their dry nature so they have a relatively long shelf life, easy to distribute, practical and commonly consumed by people, especially people with nutritional vulnerabilities. In addition, making biscuits is relatively simple and can be enriched with various additives ${ }^{(7,8)}$. The basic ingredients for making biscuits consist of wheat flour, fat or oil and sugar so that the nutritional content is incomplete, especially protein and micronutrients such as vitamins and minerals. ${ }^{(9)}$

Based on these problems, it is necessary to develop alternative foods to prevent nutritional problems. This aims of this study to determine nutrient content and acceptability of biscuit substitutes of mackerel fish flour as an alternative additional food for children under five or pregnant women who experience in malnutrition.

\section{Materials and Method}

Research Design: This study was experimental designed to assess the best acceptability and nutritional content of biscuit products based on the substitution of mackerel fish flour. The formulation of the concentration of mackerel flour substitution is grouped into four parts, namely: $0 \%$ concentration (F0), 5\% concentration (F1), $10 \%$ concentration (F2) and $15 \%$ concentration (F3). The four groups of biscuits were then tested for acceptance and analysis of the nutrient content of carbohydrates, fats, proteins, calcium, zinc and iron.

Research Place: Processing of mackerel fish flour, making biscuits and acceptance tests were carried out at the Food Technology Science Laboratory (ITP) and the Organoleptic Test Laboratory on Nutrition Department of Makassar Health Polytechnic. The analysis of the nutritional value of biscuits was carried out at the Laboratory of Animal Feed Chemistry, Faculty of Animal Husbandry, Hasanuddin University Makassar.

Table 1: Composition of ingredients for making puffed fish biscuits

\begin{tabular}{|l|c|c|c|c|c|}
\hline \multirow{2}{*}{ Material } & \multirow{2}{*}{ Unit } & \multicolumn{4}{|c|}{ Material Weight } \\
\cline { 3 - 6 } & & F0 & F1 & F2 & F3 \\
\hline Wheat flour & Gram & 100 & 95 & 90 & 85 \\
\hline Mackerel fish flour & Gram & 0 & 5 & 10 & 15 \\
\hline Margarine & Gram & 50 & 50 & 50 & 50 \\
\hline Fine granulated sugar & Gram & 65 & 65 & 65 & 65 \\
\hline Egg yolk & Gram & 2 & 2 & 2 & 2 \\
\hline Milk powder & Gram & 20 & 20 & 20 & 20 \\
\hline Cornstarch & Gram & 5 & 5 & 5 & 5 \\
\hline Room butter & Gram & 6 & 6 & 6 & 6 \\
\hline Vanilla & Sdt & $1 / 2$ & $1 / 2$ & $1 / 2$ & $1 / 2$ \\
\hline Baking soda & Sdt & $1 / 2$ & $1 / 2$ & $1 / 2$ & $1 / 2$ \\
\hline Cocoa powder & Gram & 10 & 10 & 10 & 10 \\
\hline Salt & Sdt & $1 / 2$ & $1 / 2$ & $1 / 2$ & $1 / 2$ \\
\hline
\end{tabular}

Description: $\mathrm{Sdt}=$ teaspoon

Procedure of Making Fish Flour and Biscuits: The process of making mackerel fish flour is as follows: (1) select fresh mackerel, clean its scales, fins, gills and guts; (2) put the fish in a basin and then give it and soak it in lime solution for about 15 minutes; (3) steam with lemongrass for about 30 minutes; (4) the fish is drained 
by leaving it in the open air. The fish is shredded into small sizes and separated from the bones; (5) shredded fish meat is then dried using an oven at a temperature of $550 \mathrm{C}$ for \pm 24 hours; and (6) the dried meat dregs are immediately ground and sieved to obtain a fine fish meal.

The process of making mackerel fish flour substitution biscuits is carried out in the following order: (1) weigh $50 \mathrm{~g}$ of margarine, mix $65 \mathrm{~g}$ of powdered sugar; (2) Mixer until well blended, then add 2 egg yolks then mixer again; (3) add $100 \mathrm{~g}$ of wheat flour, $6 \mathrm{~g}$ of vegetable fat (room butter), $1 / 2$ tsp of salt, $5 \mathrm{~g}$ of cornstarch, $20 \mathrm{~g}$ of powdered milk and $1 / 2$ tsp of vanilla, Mixer until blended; (4) Add the mackerel fish flour; (5) Stir evenly then add $10 \mathrm{~g}$ of cocoa powder; (6) weigh the dough $6 \mathrm{~g}$ per part, then print; (7) bake in oven $155 \mathrm{oC}$ for 15 minutes; and (8) puffed fish biscuits are ready to be served.

Data Collection Method: The assessment of the acceptance of biscuits is assessed based on organolopetic tests on aspects of color, texture, aroma and taste. The test uses an instrument in the form of a Hedonic scale with a score of $1-4$, namely $1=$ dislike, $2=$ dislike, 3 $=$ like and $4=$ very like. The test was carried out by 35 semi-trained panelists from the Department of Nutrition, Health Polytechnic of Makassar who had programmed the Food Technology course.

Analysis of the nutritional value of biscuits, namely protein content using Kjehdal method, fat content using shoxlet method, carbohydrates content using Luff Chroll method, minerals content (calcium, iron and zinc) using AAS (Atomic Absorption Spectrophotometry) method.

Data Analysis: Acceptability data in categorical form were analyzed using the Chi Square test. The scoring data were analyzed using the one-way Anova test and the Kruskal-Wallis test, to determine differences in acceptance scores. If the statistical test results are significant, then further analysis is carried out using the Tukey test.

\section{Results and Discussion}

\section{Acceptance of Biscuits:}

Table 2: Percentage (\%) of Panelists' Likeness Level in Each Biscuit Formula Based on the Receiving Aspect

\begin{tabular}{|l|c|c|c|c|c|}
\hline Acceptability & F0 & F1 & F2 & F3 & Sig \\
\hline Color: & & & & & \\
Really like & 22.8 & 5.7 & 5.7 & 8.6 & \\
Like it & 68.6 & 77.1 & 74.3 & 68.6 & 0.163 \\
Do not like it much & 8.6 & 17.1 & 20.0 & 22.8 & \\
Do not like & 0 & 0 & 0 & 0 & \\
\hline Texture: & & & & & \\
Really like & 11.4 & 5.7 & 5.7 & 5.7 & \\
Like it & 60.0 & 77.1 & 60.0 & 28.6 & \\
Do not like it much & 28.6 & 17.2 & 34.3 & 60.0 & \\
Do not like & 0 & 0 & 0 & 5.7 & \\
\hline Aroma: & & & & & \\
Really like & 17.1 & 0 & 2.9 & 2.9 & \\
Like it & 74.3 & 45.7 & 45.7 & 25.7 & \\
Do not like it much & 8.6 & 54.3 & 51.4 & 71.4 & \\
Do not like & 0 & 0 & 0 & 0 & \\
\hline Taste: & & & & & \\
Really like & 37.1 & 2.8 & 5.7 & 8.5 & \\
Like it & 54.3 & 54.3 & 42.9 & 34.3 & \\
Do not like it much & 8.6 & 42.9 & 51.4 & 54.3 & \\
Do not like & 0 & 0 & 0 & 2.9 & \\
\hline
\end{tabular}

$\mathrm{F} 0=0 \%, \mathrm{~F} 1=5 \%, \mathrm{~F} 2=10 \%$, and $\mathrm{F} 3=15 \%$ substitution of mackerel fish meal 
Chi Square test results showed that the substitution of mackerel fish flour did not affect the panelists acceptance of color $(p=0.068)$ and texture $(p=0.407)$ of biscuits. The substitution of mackerel fish flour influenced the panelists preference in the aspect of aroma $(\mathrm{p}=0.000)$ and taste $(\mathrm{p}=0.000)$ of biscuits. The higher concentration of the mackerel fish flour substitution, the less the panelists expressed their preference for the aroma and taste aspects of the biscuits.

Table 3: Acceptability Score for each Biscuit Formulation

\begin{tabular}{|l|c|c|c|c|c|}
\hline \multirow{2}{*}{ Acceptability } & \multicolumn{4}{|c|}{ Treatment } & \multirow{2}{*}{ Sig } \\
\cline { 2 - 5 } & F0 & F1 & F2 & F3 & \\
\hline Color & 3.14 & 2.88 & 2.86 & 2.86 & 0.061 \\
\hline Texture & 2.82 & 2.89 & 2.71 & 2.66 & 0.356 \\
\hline Aroma & 3.08 & 2.46 & 2.51 & 2.31 & 0.000 \\
\hline Taste & 3.28 & 2.60 & 2.54 & 2.49 & 0.000 \\
\hline Combined & 3.08 & 2.71 & 2.66 & 2.58 & 0.000 \\
\hline
\end{tabular}

$\mathrm{F} 0=0 \%, \mathrm{~F} 1=5 \%, \mathrm{~F} 2=10 \%$, and $\mathrm{F} 3=15 \%$ substitution of mackerel fish meal

Table 2. shows that the standard biscuits or without mackerel flour (F0) have the highest acceptance score for the aspects of color, texture, aroma and taste. Substitution of mackerel flour reduced the acceptance of biscuits, although the decrease was not significant in terms of color $(p=0.061)$ and texture $(p=0.356)$. A significant decrease in the acceptability score was seen in aroma aspect $(\mathrm{p}=0.000)$ and taste aspect $(\mathrm{p}=$ 0.000 ). The higher the concentration of the mackerel fish flour substitution, the lower acceptance score in both aspects $^{(10)}$.

Based on the results of the organoleptic test from the aspects of color, texture, odor, and, taste (table 1), it shows that the biscuits most favored by the panelists were the F1 formula with a concentration of $5 \%$ mackerel fish flour. This is made clear by the data from the results of the favorite score in table 2 which shows that a biscuit has the highest score is the F1 formula, both in terms of color, texture, aroma, and taste. Based on the results of statistical analysis, it shows that there is no difference in the level of preference for the panelists in the aspect of color and texture between formula F0 and other formulas. However, the data distribution of the level of preference and the value of the organoleptic test results showed that the high concentration of mackerel fish flour reduced the preference value of the panelists on the color and texture of the steak.

The result is in line with our previous research on the development of local snacks in South Sulawesi through the addition of snakehead fish flour and development of rice bran cookies and mackerel fish meal ${ }^{(6,11)}$. The addition of high snake head fish affects the organoleptic quality of local snacks. Likewise, when we developed cookies with the addition of bran flour $(25 \%)$ and mackerel $(10 \%)$ it resulted in the same conclusion that the use of this formula did not affect the acceptability of the color and texture aspects.

Our previous research also only recommended a 5\% concentration of snakehead fish meal, so as not to change the color and texture of the snacks from the original ${ }^{(6)}$.

The same result was also reported by Adele,2020(12) the addition of $20 \%$ tilapia fish meal had no effect on the results of the organoleptic test from the aspects of color and texture. The bread that substitutes tilapia fish flour to $20 \%$ has the same color and texture as bread without tilapia flour. Likewise with (Sitti Patimah, et all, 2019) the addition of $15 \%$ flying fish meal is the most preferred in terms of color, texture, aroma and taste ${ }^{(13)}$. In the research, Patimah used a combination formulation of flying fish meal (Hyrundicthysoxycephalus) and barley flour (Setaria italica).

Substitution of mackerel flour will not really affect the color of the biscuits because the basic ingredients use more flour and sugar. These materials will experience browning due to the roasting process, so that the appearance of the color of each type of biscuit is relatively the same ${ }^{(14)}$. 
The addition of mackerel flour made the textual biscuits softer so that the liking score for the texture aspect was slightly reduced in the F3 formula. However, the addition of mackerel flour with formula $\mathrm{F} 1$ has a better texture score than formula F0. The addition of fish meal in high concentrations will reduce binding capacity. Wheat flour contains gluten that binds the dough. Gluten has the ability to bind and expand dough in the manufacture of pastries such as biscuits ${ }^{(15)}$. Wheat flour is a source of gluten. whereas fish flour does not contain gluten $^{(16)}$. The addition of mackerel fish meal that is too high can affect the texture of the biscuits, causing the appearance of being less attractive, soft, easily crushed so that it can affect the panelists' acceptance of the texture of the product. odor and taste are sensory indicators that determine consumer acceptance of food products ${ }^{(10)}$. The number of panelists who said they like and really like F1 biscuits was low, namely the aroma aspect of $45.7 \%$ and the taste aspect of $57.1 \%$. The preference percentage decreases in formula F2 and formula F3. The criteria for receiving a good product are based on the results of the organoleptic test if the preference level reaches $75 \%{ }^{(14)}$.

The results of the Kruskal-Wallis analysis showed that there were differences in the acceptability score on aroma aspect $(p=0.000)$ and taste aspect $(p=0.000)$ between formulas. Further analysis with the Tukey Test shows that the standard formula (F0) is significantly different from F1, F2 and F3, both in terms of aroma and taste. Substitution of mackerel flour in biscuitmaking can affect the receptivity of aroma, and taste. Fish have a specific aroma and are difficult to remove. The distinctive smell of fishy fish creates an unfavorable aroma to snacks, there by reducing acceptance ${ }^{(6)}$. The results of this study are in line with what was found by (Purwani,2017) that the recommended addition of mackerel fish flour for making biscuits is $5 \%(2)$. The addition of fish meal more than $5 \%$ will reduce acceptance in terms of odor and taste.

The smell of food is an important sensory indicator in determining taste. The smell of food forms an important and fundamental sensory signal for taste. Aroms serves as a signal that a food is fit for consumption or not, even before the food is seen. Whether you like a food or not, can be known only by smelling its aroma, even without seeing what the food looks like ${ }^{(10,17)}$. The data of this study also showed the same result that there was a correlation between the preference score for the aroma aspect and taste aspect $(\mathrm{p}=0.000)$. The preference for the aroma aspect affects the taste aspect. The addition of recommended mackerel fish flour to preserve the taste of the biscuits is only $5 \%$. Additions that exceed this concentration will cause rejection of the product ${ }^{(2)}$.

\section{Levels of Nutrients:}

Table 4: The nutritional value of the biscuits of each formula

\begin{tabular}{|l|c|c|c|c|}
\hline \multirow{2}{*}{ Nutrients } & \multicolumn{4}{|c|}{ Formula } \\
\cline { 2 - 5 } & F0 & F1 & F2 & F3 \\
\hline Carbohydrate (\%) & 66.62 & 62.49 & 58.97 & 51.67 \\
\hline Fat (\%) & 21.14 & 18.35 & 20.11 & 22.20 \\
\hline Protein (\%) & 9.48 & 10.72 & 12.08 & 13.6 \\
\hline Calcium (\%) & 0.34 & 0.38 & 0.40 & 0.41 \\
\hline Zinc (mg/L) & 10.50 & 10.83 & 12.40 & 12.96 \\
\hline Iron (mg/L) & 225.11 & 230.95 & 246.60 & 270.94 \\
\hline
\end{tabular}

$\mathrm{F} 0=0 \%, \mathrm{~F} 1=5 \%, \mathrm{~F} 2=10 \%$, and $\mathrm{F} 3=15 \%$ substitution of mackerel fish meal

The protein content of biscuits ranged from $10.72 \%$ (F1) $-13.6 \%(F 3)$, higher than biscuits without a mixture of mackerel fish flour (F0). The higher the concentration concentration of mackerel fish flour, the higher protein content of biscuits. Compared to biscuits that use tuna flour, the results we get have a higher protein content. The protein content of tuna fish flour biscuits at a concentration of $10 \%$ was only $11.47 \%$ while the results we obtained reached $12.8 \%{ }^{(18)}$. However, the results we obtained were lower than the findings of (Sitti Patimah, et all, 2019) which reported that the protein content of mackerel reached. (Sitti Patimah, et all, 2019) used a formula of mackerel fish flour mixed with millet flour which has high protein content. Likewise (Mudjajanto, et all,2015) found that the protein content of flying fish flour biscuits (20 grams) with chocolate flavor was $20.01 \%$.

The development of biscuit products can be an alternative for providing additional food for both children under five and pregnant women. South Sulawesi is classified as an area where pregnant women suffer from malnutrition, especially chronic energy shortages. It is also hoped that the provision of additional food in the form of biscuits can prevent low birth weight (LBW) in babies who are still a health problem in this area $(5,19,20)$. 


\section{Conclusion}

1. The substitution of mackerel flour in biscuits does not affect the acceptability of color and texture aspects, but it will affect for aroma and taste, especially if the concentration of the addition is too high.

2. The recommended substitute for mackerel fish flour is $5 \%$. Concentrations that exceed this amount will reduce the aroma and taste.

3. Substitution of mackerel fish flour can increase biscuit nutrients, especially protein, iron and zinc.

Ethical Clearance: Taken from Health Polytechnic of Makassar

\section{Source of Funding : No Funding}

\section{Conflict of Interest : Nil}

\section{Reference}

1. Thariq Swastawati \& Surti. The Effect of Difference in Salt Concentration on Mackerel Peda (Rastrellinger neglectus) on Glutamic Acid Content that Gives Savory Taste (Umami). Processors and Biotechnol Has Perikan. 2014; 3 (3).

2. Purwani and Fitri. Effect of Mackerel Fish Meal Substitution (Rastrelliger Brachysoma) on Protein Levels and Biscuits Acceptability. Nutrition Nas Seminars. 2017;

3. Nadimin. The Effect of Snakehead Fish Substitution on Sago Bangke Acceptability. Food Nutrition Media. 2017; XXIV: 16-20.

4. Nalendrya I, Ilmi IMB AF. Bloated Fish Sausage (Rastrelliger Kanagurta L.) As Food Source of Omega 3.. J Food Technol App. 2016; 5 (3).

5. Sari DK, Marliyati SA KA \& GT. Organoleptic Test Formulation of Functional Biscuits Based on Cork Fish Meal (Ophiocephalus Striatus). AGRITECH. 2014; 34 (2).

6. Nadimin Nurjaya \& Retno Sri Lestari. Acceptability of South Sulawesi's Local Snacks Substituted with Snakehead Fish (Channa striata) e. Aceh Nutr J. 2018; 3 (2): 141-8.

7. Gita RSD and Danuji S. A Study on Making Functional Biscuits Using Cork Fish Flour and Leaf Flour Substitution Moringa. . Bioedusains A Biol and Science Educator. 2018; 1 (2): 155-62.
8. Zahtamal, Z., Prabandari, YS and Setyawati L. Prevalence of metabolic syndrome in company workers. Natl Public Health Journal,. 2014; 9: 11320.

9. Nadimin, Veni Hadju, Suryani As'ad, Agussalim Bukhari, Andi Imam Arundhana I. Increasing of Nutrition Status of Pregnant Women after Supplementation of Moringa Leaf Extract (Moringa Oliefera) in the Coastal Area of Makassar, Indonesia. . Indian J Public Heal Res Dev. 2019; 10 (1).

10. Maina JW. Analysis of the factors that determine food acceptability. Pharma Innov J [Internet]. 2018; 7 (5): 253-157. Available from: http://www. thepharmajournal.com/archives/2018/vol7issue5/ PartD/7-4-84-339.pdf

11. Nadimin Sirajuddin \& Fitriani N. Organoleptic Quality of Cookies with Addition of Bran Flour and Fish Mackerel. Food Nutrition Media. 2019; 26 (1): 8-15.

12. Adeleke RO OJ. Acceptability studies on bread fortified with Tilapia fish flour. Pakistan J Nutr. 2010; 9 (6): 531-4.

13. Sitti Patimah,Andi Imam Arundhana, Ansar Mursaha and Aminuddin Syam. Development of Foxtail Millet and Flying Fish Flour-Based Cookies as Functional Food. Curr. Res. Nutr Food Sci Jour. 2019; 7 (2): 504-16.

14. Winarno. Food Chemistry and Nutrition. Jakarta: Gramedia Pustaka Utama; 2002.

15. Edwards NM, Mulvaney SJ, Scanlon MG, Dexter JE. Role of Gluten and Its Components in Determining Durum Semolina Dough Viscoelastic Properties. Cereal Chem. 2003; 80 (6): 755-63.

16. Biesiekierski JR. What is gluten? J Gastroenterol Hepatol. 2017; 32: 78-81.

17. Cho S, Yoon SH, Min J, Lee S, Tokar LS et al. Variations in US Consumers' Acceptability of Korean Rice Cake, Seolgitteok, with respect to Sensory Attributes and Nonsensory Factors. J Food Sci. 2016; 81 (1).

18. Listiana L. Effect of Tuna Fish Meal Substitution on Protein Content, Hardness and Acceptability of Biscuits. Muhammadiyah Surakarta university; 2016.

19. Nadimin, Veni Hadju, Suryani As'ad, Agussalim Bukhari, Irmawati Haruna, Rudy Hartono. . Increasing of Nutrition Status of Pregnant Women 
after Supplementation of Moringa Leaf Extract (Moringa Oliefera) in the Coastal Area of Makassar, Indonesia. J Public Heal Res Dev. 2019; 10 (1).

20. Nadimin, Beni Hadju, Suryani As'ad, Agussalim Bukhari, Andi Imam Arundhana, Irmawati. comparison between extract Moringa oleifera and iron tablet on prevention of low birth weight in pregnant mothers in Makassar Indonesia. Enfermería Clínica,. 2020; 30 (4): 26-30. 